\title{
Bibliografia Comentada: Os 50 anos da Televisão Brasileira
}

\section{Resumo}

O presente texto oferece comentários críticos sobre algumas obras recentemente tomadas públicas no âmbito da comunicação social, no Brasil, sobretudo na oportunidade dos cinqüenta anos da televisão no país.

\section{Cinqüentenário televisivo}

Nos últimos meses de 2001, um volume considerável de publicações de autores, reconhecidos tanto no meio acadêmico quanto no mercado editorial, chegou às prateleiras das livrarias brasileiras. Tais obras tratam, de forma clara, sobre um dos meios de comunicação mais populares e difundidos no mundo: a televisão. Essas recentes publicações têm como característica principal uma análise que passa pela programação do audiovisual, suas técnicas de produção e por um registro da própria história deste meio.

Os cinqüenta anos da televisão brasileira aparecem resgatados na literatura especializada e cobrem um espaço ainda pouco explorado e que já há algum tempo reclamava por títulos inovadores. A linguagem não acadêmica toma-os facilmente compreensíveis e, em parte, é resultado das experiências vividas pelos autores.

Algumas dessas obras recuperam a história da televisão que sobreviveu graças ao depoimento daqueles que participaram do momento inicial da fundação das primeiras redes em caráter nacional; outras, de cunho mais acadêmico, anunciam as pesquisas feitas por docentes das universidades brasileiras tendo como recorte as produções televisivas de algumas das principais emissoras do país.

Observa-se desde o início a recorrência a temas que no fundo privilegiam as condições da produção televisiva, as peculiaridades tecnológicas utilizadas, ou os condicionantes da produção obtida. São raras as indagações envolvendo de forma mais assertiva a comunicação segundo a ótica da recepção. Nesse sentido, são estudos que lembram muitas vezes a perspectiva hegemônica do emissor, as condições de produção e os produtos derivados, tônicas que marcam até agora as perspectivas apoiadas nas posturas teóricas fundadoras em comunicação.

Parte desses textos, apesar de utilizar o modelo funcionalista para explicar a tecnologia midiática, adota a Teoria Crítica para apontar o maniqueísmo existente no meio de comunicação, segundo o qual ele exerce um poder de persuasão, sedução, convencimento sobre o telespectador. As recentes publicações sobre televisão têm- se caracterizado em propor este veículo como produto de consumo, simbólico ou material, no qual o emissor é o principal responsável.

Esse é o sentido que perpassa $O$ Circo Eletrônico - Fazendo TV no Brasil, de Daniel Filho. O autor foi diretor, editor executivo, produtor e ator da Rede Globo de Televisão e a multiplicidade de papéis exercidos por ele conferiu-lhe legitimidade no assunto. Assim, ele se apropriou do título usado anteriormente por Nelson Pereira dos Santos ao referir-se sobre a decadência do cinema, ao mesmo tempo em que faz alusão à diversidade de temas utilizados pelo meio e pela inserção deste junto ao
Ronaldo Mathias é doutorando em Ciências da Comunicação pela ECA USP e professor da Faculdade de Belas Artes de São Paulo

Wildney Feres Contrera é mestre em Ciências da Comunicação e professora junto à Unicsul - SP 
grande público que lhe dá um caráter popular.

Filho narra a história da televisão em seus primórdios e as dificuldades enfrentadas por aqueles que, de forma amadorista, souberam aproveitar $\mathrm{o}$ melhor do rádio e do cinema para criar as primeiras produções televisivas. A ótica do produtor de TV, que prevalece na obra, preocupa-se em trazer ao leitor como se faz um audiovisual e como momentos da história do país foram retomados como geradores dessas produções. Algumas das obras registradas por Filho representam uma releitura da cinematografia brasileira, com características bem populares.

Neste aspecto, a popularidade de tais obras vai ao encontro do que se refere Martín-Barbero quando este menciona o caráter nacionalista, por exemplo, das teledramaturgias latinoamericanas. Para Barbero “(...) la telenovela ocupa un lugar determinante en la capacidad nacional de producción televisiva, esto es la consolidación de la industria televisiva, en la modemización, de sus procesos e infraestructuras - tanto técnicas como financieras - y en la especialización de sus recursos: libretistas, directores, camarógrafos, sonidistas, escenográfos, editores. La producción de telenovelas significó a su vez una cierta apropiación del género por cada país: su nacionalización" ${ }^{1}$. A afirmação de Daniel Filho ao dizer que a centralização da produção, a padronização e sistemas de administração operada pela Rede Globo abriu espaço para a criação de um produto televisivo puramente nacional, atesta o pensamento de Barbero.

Os grandes clássicos da televisão brasileira, como Véu de Noiva, Irmãos Coragem, Roque Santeiro e $O$ Bem Amado, surgem retratados no livro onde aparecem detalhes tanto da produção quanto da vida e dificuldade dos artistas na realização dessas peças. O livro de Daniel Filho, além de ter o olhar do produtor sobre o meio de comunicação mais sedutor do país, traz com ele os takes dessas produções ricamente ilustradas e que o faz fonte de referência para consulta aos interes- sados no tema.

A onda comemorativa dos 50 anos da TV não parou com a edição do livro de Daniel Filho que retratou a produção da Rede Globo, ícone da mídia eletrônica brasileira. Outras obras como A Deusa Ferida, organizada por Silvia Borelli e Gabriel Priolli, também trilharam pela historiografia da televisão e teve como tema a mesma rede televisiva, e que, apoiada nos estudos de audiência, tentaram compreender e entender a crise que a emissora registra nos últimos anos.

Os autores recorreram a uma análise dos fatos que envolvem a Rede Globo na busca de uma resposta que não fosse o resultado das variações de humores dos seus críticos, mas que fosse, antes de tudo, assentada na produção científica - dados foram mensurados e obtidos por meio de pesquisa, resultados de audiência que envolvem a Globo da época do seu nascimento até meados de 1970.

A pesquisa realizada entre maio e julho de 1999 por professores das áreas de Ciências Sociais e Comunicação da Pontifícia Universidade Católica de São Paulo voltou-se para os receptores das mensagens da Rede Globo, adotando, para isso, uma análise qualitativa dos dados obtidos que foram comparados com comportamentos do público receptor. Esse estudo centrou-se no "padrão de qualidade", tido como característica principal da emissora, e representado, principalmente, pelas telenovelas e o jornalismo, o prime time da Globo.

Para alcançar esses resultados foi utilizado o modelo de pesquisa qualititativa - Quali, "que tem como estratégia a formação de grupos de discussão para avaliação do comportamento do público receptor na atualidade" (p.14). Foram usados oito grupos, em dois sítios principais: São Paulo e Rio de Janeiro.

Dessa forma, o livro se divide em dois blocos: no primeiro, analisa a oscilação de audiência nas telenovelas e jornalismo e faz uma reflexão sobre o padrão de qualidade da Rede Globo. No segundo bloco, analisa os fatores externos da perda de audiência: concorrên- 
cia, segmentação na televisão aberta (VHF e UHF), as especificidades da regionalização, a concorrência com a televisão paga, transformações sócio econômicas, e a influência das novas tecnologias no cotidiano do receptor e a análise dos principais programas que concorrem com a emissora. Nesta última fase, a análise se deteve na televisão aberta.

O livro toma o caminho da historiografia da televisão brasileira e os avanços obtidos com o uso de uma tecnologia de ponta e a formação de quadros profissionais específicos para essa nova etapa dos media no país.

Por outro lado, para que a análise pudesse ser feita, a história da televisão brasileira é contada com riqueza de detalhes e, nesse aspecto, não acrescenta ao que já foi descrito por Daniel Filho em Circo Eletrônico.

Esse resgate da história da televisão nos remete à retomada do processo da instauração do meio no país, tendo como suporte teórico a discussão das indústrias culturais ${ }^{2}$, a cultura subordinada simultaneamente aos interesses do Estado de exceção dos anos 60 ao final dos anos 80 e aos interesses comerciais. Esses fatores, entre outros, são apontados pelos autores como os desencadeadores do crescimento de uma indústria televisiva apoiada na idéia de um padrão global, que envolveu a tecnologia e se aproveitou do aparecimento do videoteipe com uma proposta de desenvolver o "projeto prime-time". Esse projeto condensado teve um objetivo: monopólio da audiência.

O objetivo do livro é, portanto, um estudo sobre audiência cujo enfoque repousa nos Estudos Culturais, a exemplo de David Morley, pesquisador inglês, da Escola de Birminghan que foi pioneiro nessa área com seu estudo sobre a Nationwide Audience.

Ao contrário do que se possa pensar, o livro $A$ Deusa Ferida não é um estudo sobre a pseudoqueda, ou o débaque da Rede Globo, como podem pensar os mais pessimistas. Ele mostra a trajetória de uma rede televisiva que ainda detém o poder, mas que aos poucos se fragmenta em detrimento de diferentes interesses do público, quer seja na grade de programação, quer seja na identificação do público com essa programação, na possibilidade de ter novas opções que não restrinjam o telespectador a uma ou duas emissoras.

São apenas fatores, dado a existência de novas opções, como novas emissoras de pay per view, a existência de novos medias como a internet, ou ainda porque, depois de tantos anos no ar, os programas se desgastam e perdem o encantamento inicial.

Destoando do caminho adotado por Daniel Filho, Borelli e Priolli no livro 50 Anos de TV coordenado por Eugênio Bucci retoma trabalhos acadêmicos de vários pesquisadores e os condensa em uma única obra cuja proposta do organizador é sintetizada “(...) criticar a televisão tem sido fundamental, um exercício de utilidade pública. Um exercício urgente e inadiável."

Dentro dessa perspectiva, os textos foram pensados não só em função de uma data, mas de datas comemorativas na qual a comemoração dos 500 anos de Brasil está incluída. Nesse sentido, os artigos pensam o meio em função de como o país cresceu e desenvolveu suas políticas comunicacionais e como a televisão tem contribuído para a reconfiguração do espaço público na integração do povo brasileiro.

Os textos incluídos na obra são críticos da produção televisiva, porém a leitura que se faz deles é que ainda se concentram na conhecida fórmula da teoria crítica, no qual o meio não é visto pelo olhar do receptor, mas como um instrumento de cooptação e indução ao consumo pelo público.

$\mathrm{O}$ artigo de Bucci é o melhor exemplo da afirmação acima, a narrativa adotada empenha-se por demonstrar que a identidade do povo brasileiro foi forjada a partir de interesses políticos ideológicos e econômicos, e imposta verticalmente. "Há mais para ser dito: a cloaca, ou o arremedo de uma antropofagia transfigurada em indústria a que chegamos, não recicla o que nos seria estrangeiro e o que nos seria reprimido em nosso próprio passado, o que nos seria inédito, mas apropria-se de tudo
(2) A indústria cultural, para Adorno, é um processo verticalizado para manipulare determinar às massas populares 0 que elas devem consumir - traco típico do mundo industrializado, e capitalista sedimentado na téconica e na ciência, e que priva os sujeitos de seus desejos mais básicos. Ao mesmo tempo, essa indústria os incita a consumir cada vez mais. Esse pensamento não foi abandonado. Ao contrário, quanto mais a sociedade se transforma em consumidora de bens simbólicos ou materiais, mais a teoria crítica ganha novos adeptos. (N.A.A.) 
indistintamente, indo da pilhagem à pasteurização num único segundo", (p. 127). A estética da televisão e sua glamourização servem como catalisador e venda aos olhos, além de promover o distanciamento do povo para com os problemas reais vividos no cotidiano.

Como o livro foi organizado, ele permite que se conheça a historiografia da televisão brasileira porque, ao criticála os autores retomam fatos ocorridos e os inserem em um determinado moment histórico: fatos e gêneros televisivos se confundem.

Contrapõe-se a essa corrente de pensamento o livro A televisão levada à sério, de Arlindo Machado, que, segundo o posfácio, é "a primeira obra brasileira a analisar a televisão com foco no seu conteúdo (...) colocando a qualidade como a questão principal a ser avaliada".

Machado apresenta outras possibilidades ao meio e retoma a necessidade de torná-la dialógica junto ao espectador. O conceito de ideologia para o autor toma a forma de idéia, segundo pensamento socrático, que tem por sustentação a oralidade que está presente no rádio e na TV. Assim, para ele, a televisão é um meio que estimula o debate e se apresenta como nova possibilidade para desenvolver o pensamento da sociedade, assim como permi que sejam afloradas outras formas discursivas e mais antigas que residem na cultura de um povo. Contudo, o diálogo ocorrido na TV emerge sob a pressão do tempo que restringe a autonomia discursiva necessária ao telespectador.

Para o autor, pesa a qualidade daqueles que produzem, apresentam e participam nesses diálogos midiáticos, o que confere ainda à TV o papel de protagonista e o telespectador apenas como coadjuvante do processo de recepção.

A televisão levada a sério explora ainda a questão dos gêneros, suas linguagens e tecnologias, uma abordagem cara a Machado quando se pretende analisar a qualidade neste meio. $\mathrm{O}$ autor apresenta a construção dos gêneros no Brasil e no mundo, estabelecendo uma comparação entre a produção existente nos diversos países que adotam temas semelhantes.

Esses títulos apontam na direção de uma história da televisão que está sendo construída sob óticas diferentes neste momento comemorativo dos seus cinqüenta anos. Percebe-se que existem novas pesquisas sobre os estudos de televisão apoiadas em teorias de comunicação bem como o resgate histórico do meio, ambos servindo de referências para pesquisadores, estudantes e interessados no assunto.

\section{Bibliografia do Artigo}

BORELLI, Silvia, e PRIOLLI, Gabriel (org). A deusa ferida: por que a Rede Globo não é mais campeã absoluta de audiência. SP:

Summus, 2000

BUCCI, Eugênio(org). A TV aos 50 - Criticando a Televisão Brasi-

leira no seu Cinqüentenário. SP: Editora Fundação Perseu Abramo, 2000.

FILHO, Daniel. O circo eletrônico - Fazendo TV no Brasil. RJ:

Ed. Jorge Zahar, 2000.

MACHADO, Arlindo. A televisão levada a sério. São Paulo: Editora

Senac, 2000. 